\title{
An Archaeological Survey for the Bexar County Correctional Facility at Cagnon Road, San Antonio, Texas
}

Diane A. Cargill

Center for Archaeological Research

Brett A. Houk

Center for Archaeological Research

David L. Nickels

Follow this and additional works at: https://scholarworks.sfasu.edu/ita

Part of the American Material Culture Commons, Archaeological Anthropology Commons, Environmental Studies Commons, Other American Studies Commons, Other Arts and Humanities Commons, Other History of Art, Architecture, and Archaeology Commons, and the United States History Commons

Tell us how this article helped you.

This Article is brought to you for free and open access by the Center for Regional Heritage Research at SFA ScholarWorks. It has been accepted for inclusion in Index of Texas Archaeology: Open Access Gray Literature from the Lone Star State by an authorized editor of SFA ScholarWorks. For more information, please contact cdsscholarworks@sfasu.edu. 


\section{An Archaeological Survey for the Bexar County Correctional Facility at Cagnon Road, San Antonio, Texas}

\section{Creative Commons License}

\section{(c) (1) \&}

This work is licensed under a Creative Commons Attribution-NonCommercial 4.0 International License 


\title{
An Archaeological Survey for the Bexar County Correctional Facility at Cagnon Road, San Antonio, Texas
}

\section{Diane A. Cargill, Brett A. Houk, and David L. Nickels}

\author{
Robert J. Hard and C. Britt Bousman
}

Principal Investigators

Texas Antiquities Permit No. 1954

Ccopyright 1998

Center for Archaeological Research The University of Texas at San Antonio Archaeological Survey Report, No. 285 
The following information is provided in accordance with the General Rules of Practice and Procedure, Chapter 41.11 (Investigative Reports), Texas Antiquities Committee:

1. Type of investigation: Survey

2. Project name: Bexar County Correctional Facility

3. County: Bexar

4. Principal investigators: Robert J. Hard and C. Britt. Bousman

5. Name and location of sponsoring agency: Kell Muñoz Wigodsky/Saldona \& Associates, 700 N. Tower, Suite 700, 800 N.W. Loop 410, San Antonio, Texas 78216

6. Texas Antiquities Permit No.: 1954

7. Published by the Center for Archaeological Research, The University of Texas at San Antonio, 6900 N. Loop 1604 W., San Antonio, Texas 78249-0658, 1998

A list of publications offered by the Center for Archaeological Research is available. Call (210) 458-4378; write to the Center for Archaeological Research, The University of Texas at San Antonio, 6900 N. Loop 1604 W., San Antonio, Texas 78249-0658; e-mail to car@lonestar.utsa.edu; or visit CAR's web site at http://www.csbs.utsa.edu/research/car/index.htm. 


\begin{abstract}
An archaeological survey was conducted near Cagnon Road by the Center for Archaeological Research of The University of Texas for Bexar County. The project area is the proposed location for the Bexar County Correctional Facility. Intensive pedestrian survey and backhoe trenching were employed to determine the presence and depth of cultural material in the project area. One prehistoric site, characterized by a surface lithic scatter, was identified. Due to thin topsoil and agricultural activities, the site exists in a disturbed context. Furthermore, the presence of shallow Cretaceous age subsoil precludes finding buried in situ cultural material in the project area. Since the Bexar County Correctional Facility will not negatively impact intact cultural deposits it is recommended that construction be allowed to proceed.
\end{abstract}




\section{Contents}

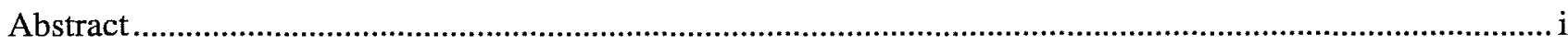

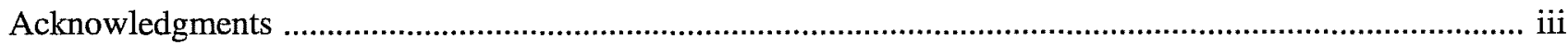

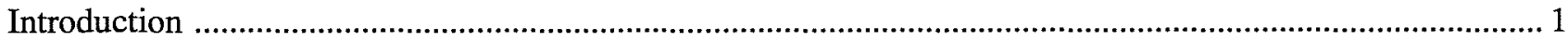

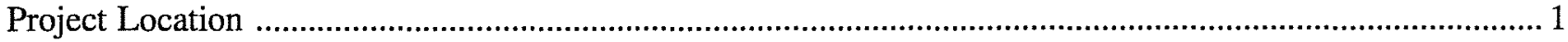

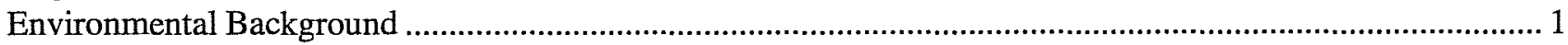

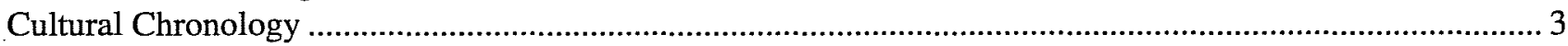

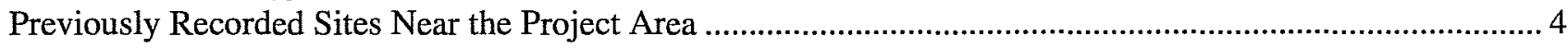

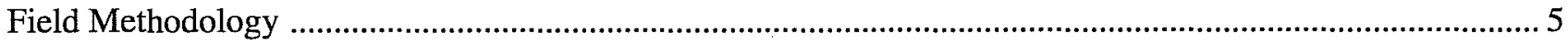

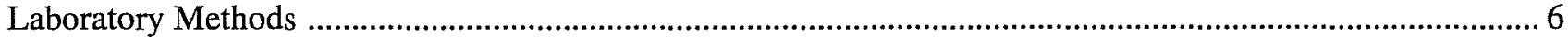

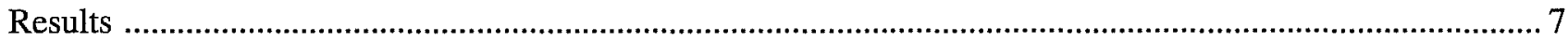

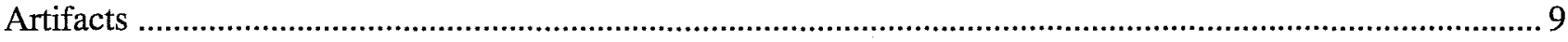

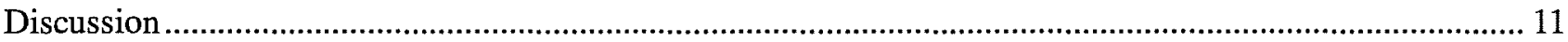

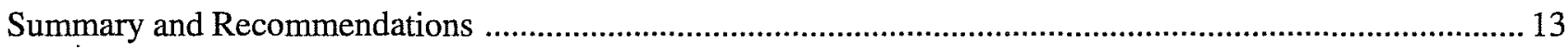

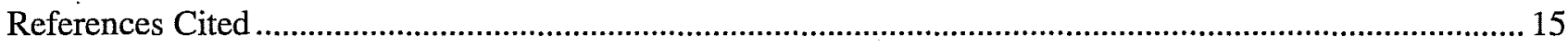

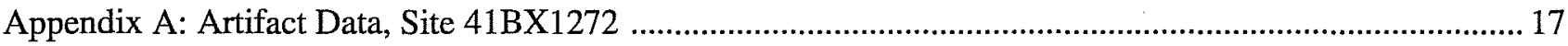

\section{Figures}

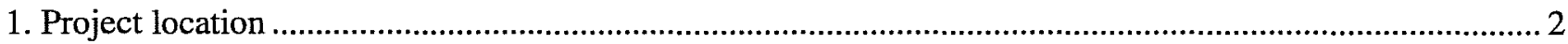

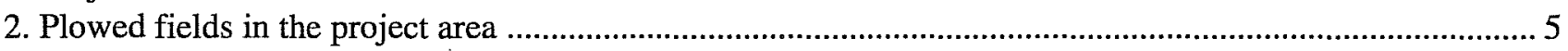

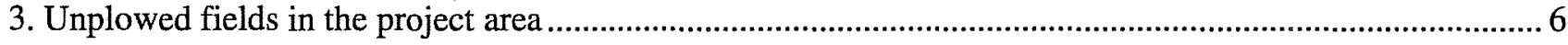

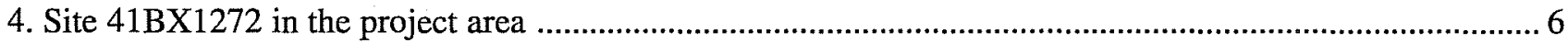

5. Map showing project boundary, plowed and unplowed fields, site 41BX1272,

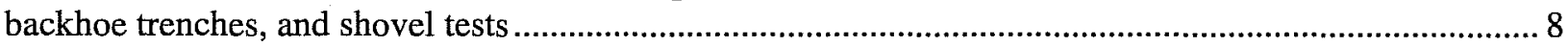

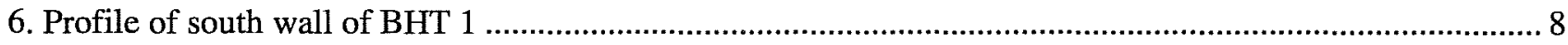

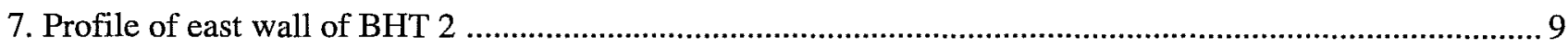

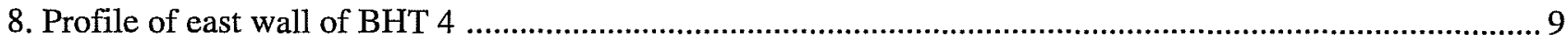

\section{Tables}

1. Contingency Table Analysis of Number of Artifacts by Category at Each Site ..................................... 12

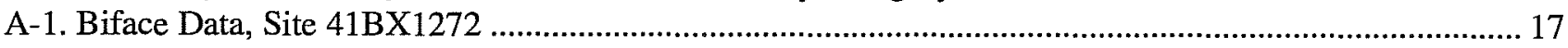

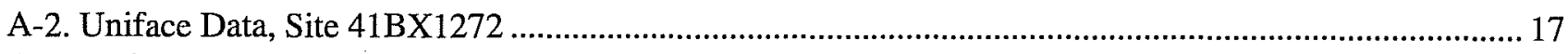

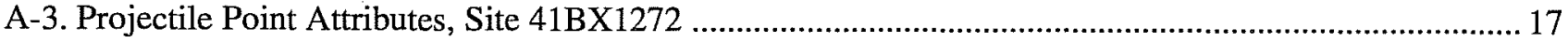

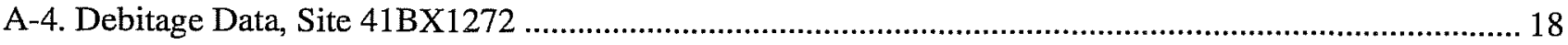

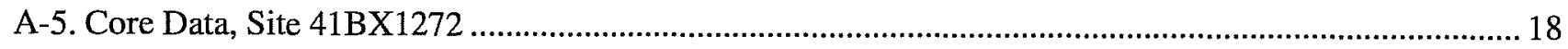

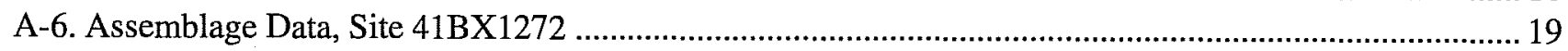




\section{Acknowledgments}

Several people have contributed in various ways to the completion of this project. I would like to thank Mr. Robert Diaz de Leon of Bexar County, Mr. Benito Polendo from Kell Muñoz Wigodsky, Inc., and Mr. René Garcia from H. B. Zachary Co., for their assistance during the course of this project. Thanks also to Mr. H. E. Kinker and Mr. Clyde Finch of the Texas Department of Criminal Justice, and Martin Parks and David Clarke for their help in the field. Cynthia Tennis, manager of this project, was especially insightful and helpful. Mike Fulgham from Wrightway Backhoe Service, did an excellent job and provided us with valuable information about the project area. A dedicated field crew is critical to any archaeological investigation; therefore, I would like to acknowledge Donna Edmondson, Owen Ford, Kevin Hanselka, Chris Horrell, Richard Jones, Kimberly Kvernes, Tony Lyle, Ruth Mathews, and Preston McWhorter, and student interns Clemente Murguia and Gloria Murguia. Thanks goes to Bruce Moses for mapping the project area, and to Bruce Moses and Chris Butler for drafting the figures found in this report. A special recognition is made to our technical editor, Marcie Renner, for her expertise and assistance. 


\section{Introduction}

An archaeological survey was conducted by the Center for Archaeological Research (CAR) of The University of Texas, from March 2 through March 11, 1998, for Bexar County. In compliance with the Texas Antiquities Code, the archaeological work was necessitated by the County's proposed plans to construct the Bexar County Correctional Facility immediately south of the Texas Department of Criminal Justice near Highway 90 and Cagnon Road. The work was performed under Texas Antiquities Permit No. 1954. The project area is approximately 91 acres, of which plowed fields comprise 77.5 acres, and unplowed fields make up the additional 13.5 acres. In order to determine the presence of cultural materials, an intensive pedestrian survey was conducted, and four shovel tests and five backhoe trenches were excavated within the project area. The work was performed in 21 person days. Robert J. Hard and C. Britt Bousman served as principal investigators, and Diane Cargill as project archaeologist.

\section{Project Location}

The project area lies south of Highway 90 and west of Cagnon Road in western Bexar County, Texas (Figure 1). It is located approximately $1.25 \mathrm{~km}$ north of the confluence of Potranco Creek and the Medina River. This upland area is relatively flat having an elevational range between 660 and $670 \mathrm{ft}$ above mean sea level. A visual inspection of the project area and a review of the Macdona Quadrangle Map indicate that some degree of land modification has occurred in the past.

\section{Environmental Background}

The project area is located south of the Balcones Escarpment in the northern Gulf Coastal Plain physiographic region. Further division of this major physiographic region, based on topographic and biotic associations, places the project area in the geographic region known as the Blackland Prairie (Black 1989a).

\section{Climate}

The climate of Bexar County is classified as modified subtropical, characterized by mild winters and hot summers (Taylor et al. 1991). Daytime humidity ranges from 50 to 80 percent throughout the year, while clear skies prevail over 70 percent of the summer and 50 percent in winter. The coldest average month is January (average temperature: $62.3^{\circ} \mathrm{F}$ ), and the hottest average month is August (average temperature: $94.2^{\circ} \mathrm{F}$ ) (Taylor et al. 1991). Rainfall averages 27.89 inches (Taylor et al. 1991:Table 11), but a great deal of variation exists from year to year, with 52.28 inches recorded in 1973 and 10.11 inches recorded in 1917 (McGraw and Hindes 1987:37).

\section{Geology and Soils}

The geology of the project area is mapped as the Upper Cretaceous Navarro Group and Marlbrook Marl. The upper part of this formation is comprised of marl, clay, sandstone, and siltstone, with a thickness of up to $580 \mathrm{ft}$. The lower part, $400 \mathrm{ft}$ thick, is composed of clay which weathers to a very thick, black, clayey soil (Barnes 1983). The soil is mapped as Houston Black gravelly clay with 1 to 3 percent slopes (Taylor et al. 1991). Located on the uplands and along drainageways, this soil contains gravels ranging in size from 0.5 to 3 inches in diameter.

\section{Flora and Fauna}

The study area lies within the Blackland Prairie vegetational area which is characterized by a mix of tall grass species (Ricklis and Collins 1994). These include little bluestem (Schizachyrium scoparium), big bluestem (Andropogon gerardi), indiangrass (Sorghastrum avenaceum), switch grass (Panicum virgatum), sideoats grama (Bouteloua curtipendula), and hairy grama (Bouteloua hirsuta) (McCulloch and Voellinger 1996). Oak mottes are typically found in the upland areas, and larger stream riparian zones contain oak, pecan, walnut, hackberry, sumac, bald cypress, and cottonwood trees. Mesquite is common to 


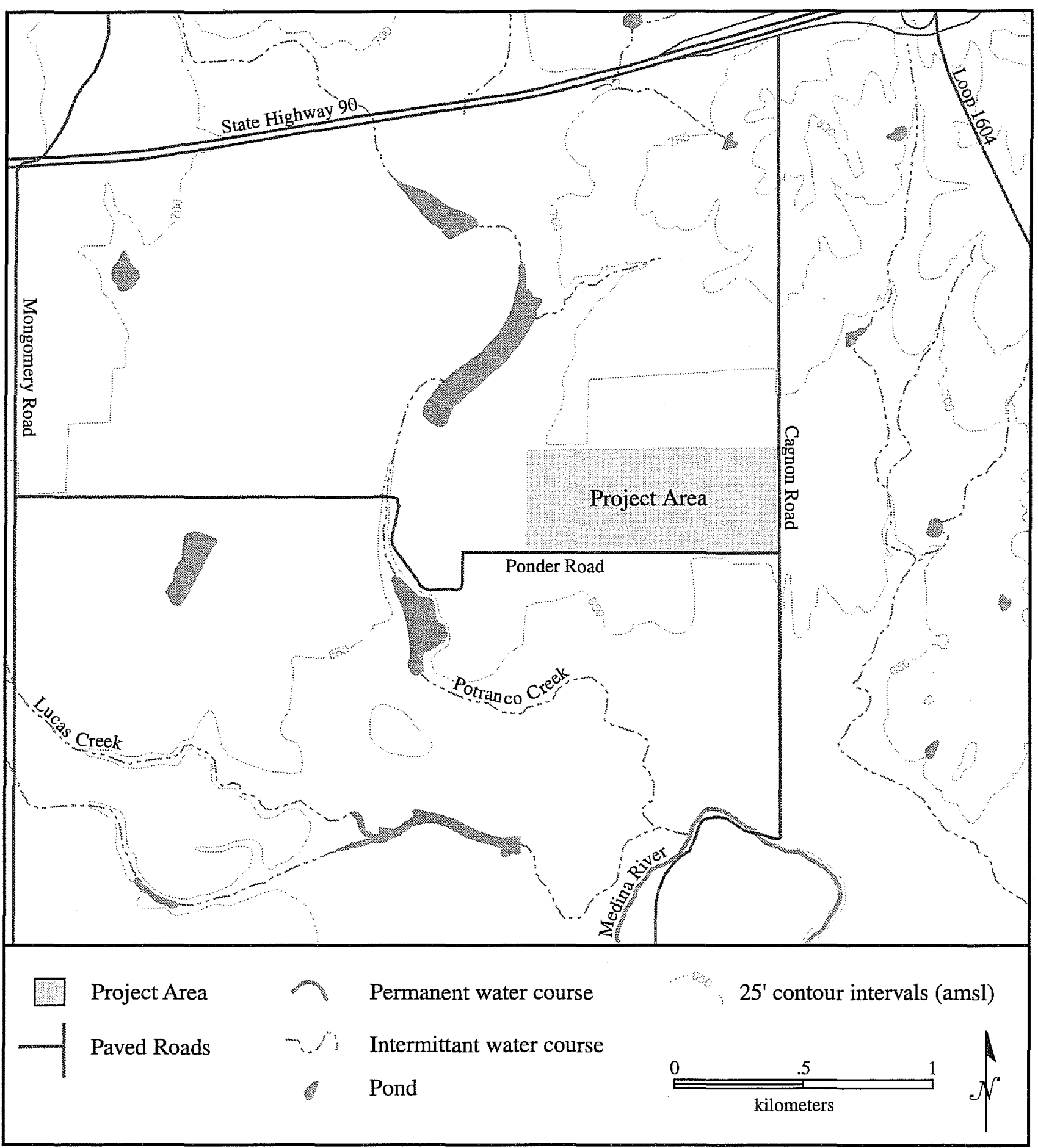

Figure 1. Project location.

higher stream terraces, but is also present in the deep soils of gentle upland slopes (Ricklis and Collins 1994). The Blackland Prairie vegetational area is included in the Texan Biotic province defined by Blair
(1950). Blair identifies 49 species of mammals, two land turtles, 16 lizards, 39 snakes, and 23 amphibians within this province. 


\section{Cultural Chronology}

\section{Paleoindian}

The Paleoindian period in Central Texas spans approximately 3,000 years from 11,500 to 8,800 B.P. (Collins 1995). Two subperiods-Early Paleoindian (11,500-10,000 B.P.) and Late Paleoindian (10,0008,800 B.P.) - have been identified. Lanceolate projectile points associated with the early subperiod are Clovis, Folsom, and Plainview. Those of the late subperiod include Golondrina, Angostura, Scottsbluff, and Meserve (Black 1989b). Artifacts from the Paleoindian period are commonly found on the surface as isolated finds; however, camp, quarry/stoneworking, kill, cache, ritual, and burial sites have been reported (Collins 1995). Early Paleoindians have typically been described in the archaeological literature as nomadic, specialized "big game" hunters in pursuit of now-extinct Late Pleistocene fauna such as mammoth and Bison antiquus. With the extinction of these species, a specialized hunting strategy continued through the Late Paleoindian period but the target of prey shifted to other large herbivores such as Bison bison and deer (Odocoileus). As more data on early Paleoindian subsistence is recovered, however, the perception of "big game" hunters is giving way to "well adapted, generalized hunters-gatherers with the technology to hunt big game but not the need to rely exclusively on it" (Collins 1995:382).

\section{Archaic}

The Archaic period in Central Texas spans approximately 7,500 years, from 8800 to $1200 / 1300$ B.P. (Collins 1995). Three subperiods-Early Archaic (8800-6000 B.P.), Middle Archaic (6000-4000 B.P.) and Late Archaic (4000-1200 or 1300 B.P.) - have been identified. Changes in projectile point styles, a more localized geographic distribution of artifacts, an increase in the number of sites, and the presence of burned rock scatters, hearths, and middens, serve to separate the Archaic from the Paleoindian period (Collins 1995).

\section{Early Archaic}

The Early Archaic period is characterized by Gower, Hoxie, Wells, Bell, Andice, Uvalde, Martindale, Baird, and Taylor (Early Triangular) projectile points (Collins and Ricklis 1994). Additional diagnostic artifacts from this subperiod include unifacial and bifacial Clear Fork tools, and the bifacial Guadalupe tool (Black 1989b; Collins 1995). While Early Archaic tools are found beyond Central Texas, implying "broad settlement patterns and resource utilization" (Trierweiler et al. 1995:31), a concentration of early Archaic components located close to the eastern and southern borders of the Edwards Plateau (Black 1989b; Collins 1995) along the Balcones Escarpment has been documented. One explanation for this apparent pattern targets the availability of water along the escarpment during an arid climatic interval (Black 1989b). Recovered subsistence remains demonstrate the exploitation of deer, small mammals, reptiles, amphibians, and fish. The intensified use of plant resources is indicated by the cooking of cammus bulbs in earth ovens (Collins 1995). Early Archaic hunters and gatherers are considered to have been organized into small, highly mobile bands, with low population densities (Weir 1976).

\section{Middle Archaic}

The Middle Archaic is characterized by Nolan, Travis, Bulverde, Pedernales, Marshall, Williams, and Lange stemmed projectile points (Collins and Ricklis 1994). In comparison to the Early Archaic, the Middle Archaic is represented by an increase in the number of sites, site size, and number of diagnostic artifact types (Collins and Ricklis 1994). Weir (1976) proposes that the observed increase in site density during this period was a direct result of increased population density.

Burned rock features, including scatters, hearths, and middens, are hallmarks of the Middle Archaic period in Central Texas (Collins 1995). The number of burned rock middens increases, and the maximum size and thickness of these features are reached during this period (Collins and Ricklis 1994). Several ideas regarding the function of burned rock middens have been 
offered; however, it is commonly accepted that their presence is directly linked to food processing. Subsistence remains recovered from burned rock middens include deer, acorns, and charred bulbs.

\section{Late Archaic}

The Late Archaic is characterized by Marcos, Castroville, Montell, Ensor, Frio, Fairland, and Darl points (Collins and Ricklis 1994). The number of sites and components reaches an all-time high in the Late Archaic period of Central Texas prehistory (Trierweiler et al. 1995). If site density is an accurate indicator of population density, it appears that the prehistoric population of Central Texas peaked at this time (Trierweiler et al.1995). For the first time in the prehistory of Central Texas, cemeteries became part of the archaeological inventory of site types. Relatively large trade networks are indicated by the presence of marine shell in cemeteries, and corner tang knives have been recovered throughout Texas and beyond (Trierweiler et al.1995). As for burned rock, "accumulating evidence supports continued and possibly increased use, throughout the Late Archaic" (Trierweiler et al.1995:33).

\section{Late Prehistoric Period}

The Late Prehistoric period in Central Texas spans approximately 800 years, from 1150 to 350 B.P. (Black 1989b). Two phases identified within this period are the Austin (1150-650 B.P.) and Toyah (650-350 B.P.). The Late Prehistoric period is characterized by changes in point style and ceramic manufacture (Trierweiler et al.1995). The presence of small arrow points (Edwards, Scallorn, and Perdiz) indicates a change to bow and arrow technology (Collins 1995).

The Austin phase is considered to be a continuation of the Late Archaic adaptation with an equal emphasis on both hunting and gathering (Collins and Ricklis 1994). Similarly, cemeteries containing marine shell artifacts remain in use during this time.

Based on the presence of bison remains and a tool assemblage comprised of Perdiz arrow points, large unifacial end scrapers, and beveled bifacial knives, Toyah phase sites reflect a shift in the exploitation of resources (Collins and Ricklis 1994). This tool assemblage is believed to be associated with the hunting and processing of bison; however, Toyah phase components such as the Mustang Branch site on Onion Creek (Ricklis 1994) and the Panther Springs and Hinojosa sites of South Texas, demonstrate the continued importance of deer (Black 1989c). The manufacture of ceramics occurs sometime after 650 B.P. (Trierweiler et al.1995). Recent data indicate that burned rock midden technology was still in use during the Late Prehistoric period (Black 1996; Tennis 1996; Trierweiler et al. 1995).

\section{Historic Period}

European presence in Central Texas may have occurred as early as the mid-sixteenth century when the de Soto expedition traveled from northeast Texas, southwestward along the Balcones Escarpment as far as the New Braunfels area (Bruseth 1992). It was not until 1684, however, that the northern frontier of Tejas became an important consideration for Spain, brought about by the French presence in East Texas (Bannon 1979). Subsequently, several Spanish missions were constructed in the late-seventeenth and early- to mideighteenth centuries in east, central, and south Texas.

In addition to various factors of change induced by French and Spanish colonization efforts, the horse and European disease are cited as two important causes of the biological and social disruption of Native American groups indigenous to Texas (Collins and Ricklis 1994). By the mid- to late-nineteenth century, "the more than 11 millennia of Native American presence in the area came to an end" (Collins 1995:387).

\section{Previously Recorded Sites Near the Project Area}

Numerous archaeological sites have been documented in the vicinity of the project area, due in large part to intensive surveys conducted by CAR at nearby Lackland Air Force Base in 1994 and 1995 (Nickels et al. 1997). Sixty-eight prehistoric, three historic, and 
four prehistoric/historic sites were recorded at Lackland. The prehistoric site types include open campsites and/or lithic quarries. Based on observed diagnostic projectile points and tools, human occupation is represented from the Early Archaic through the Late Prehistoric periods (Nickels et al. 1997).

In 1990 the Covel Gardens landfill survey (south of Lackland AFB) resulted in the documentation of prehistoric site 41BX873 (Potter 1990). Given the artifact assemblage, Potter (1990) suggests that the site represents a chert procurement and reduction locus used by prehistoric populations. Site 41BX1150, located along FM 143 between Cagnon Road and Loop 1604 , was documented in September 1995. The western end of $41 \mathrm{BX} 1150$ is approximately $75 \mathrm{~m}$ from the northeast corner of the current project area. Site 41BX1150 extends from the intersection of FM 143 and Cagnon Road, eastward approximately $1.3 \mathrm{~km}$ along FM 143 to Loop 1604. The site consists of a scatter of flakes, bifaces, and burned rock. For a more complete review of archaeological sites in the area the reader is referred to McGraw and Hindes (1987), Nickels et al.(1997), and Nickels et al. (1998).

\section{Field Methodology}

Due to the presence of plowed and unplowed fields, hree different methods were employed to determine the presence and depth of cultural resources in the project area. Plowed fields represent approximately 84 percent, and unplowed fields 16 percent of the project area (Figures 2 and 3). Initially an intensive pedestrian survey was conducted in recently plowed areas where ground surface visibility was excellent. Pedestrian transects running north/south, were spaced at 15-m intervals and all cultural material observed on the ground surface was flagged. Upon completion of the survey, CAR archaeologists returned to areas containing cultural materials to determine whether the flagged artifacts constituted an archaeological site.

The remaining unplowed fields were tested for cultural resources by excavating four backhoe trenches (BHTs). In addition, one backhoe trench was placed within the boundaries of an identified site located in the plowed area. The backhoe trenches were 3-4 m long and 1-1.5 m deep. Since the five backhoe trenches had similar stratigraphy, only BHTs 1,2 , and 4 were

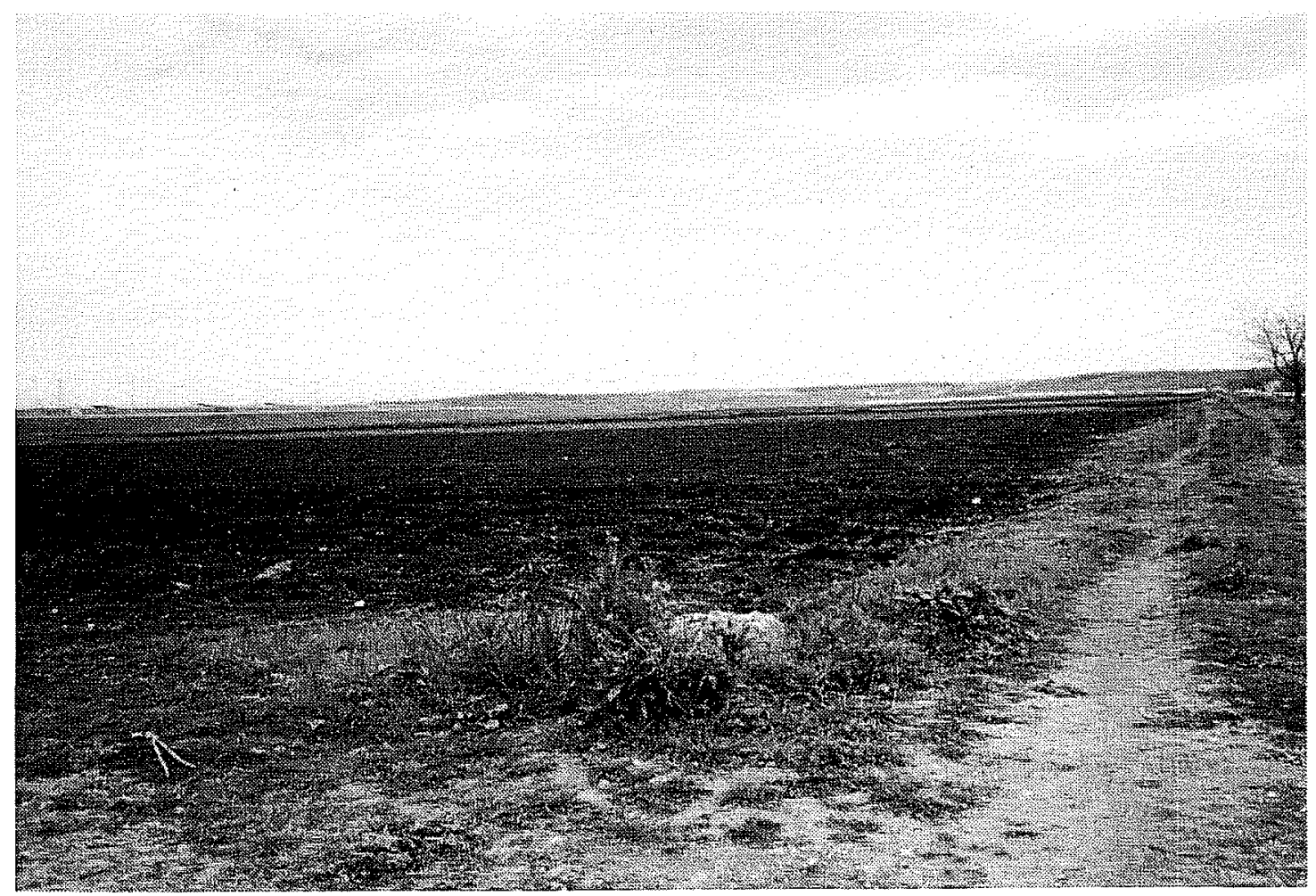

Figure 2. Plowed fields in the project area. 


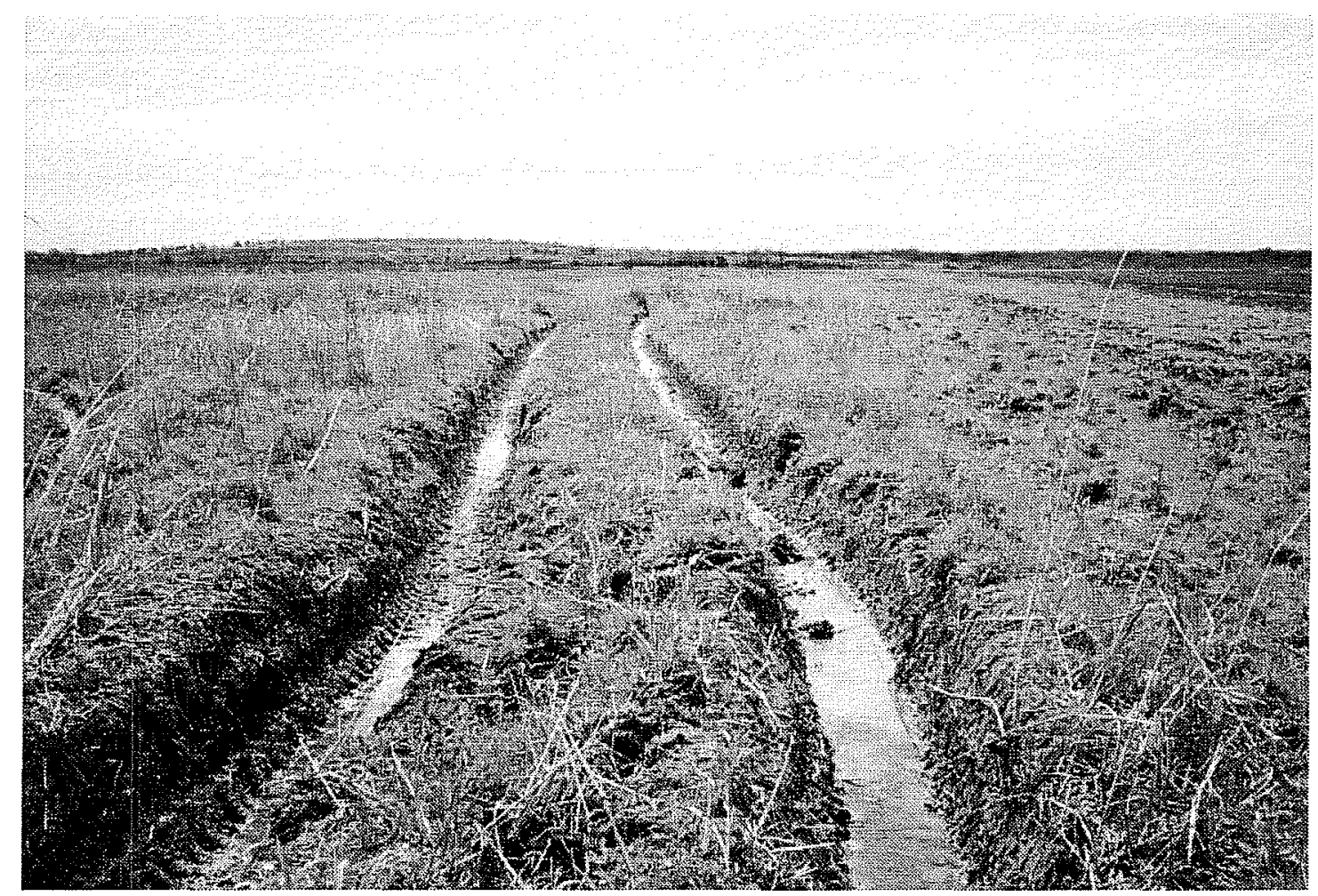

Figure 3. Unplowed fields in the project area.

profiled. Four shovel tests (STs 1-4) were excavated within the identified archaeological site to determine the vertical depth of cultural materials. The shovel tests were approximately $30 \mathrm{~cm}$ in diameter and excavated in 10-cm arbitrary levels to a depth of $50 \mathrm{~cm}$ below surface (bs). All soil matrix was screened through $1 / 4$-inch wire mesh. Shovel test information was recorded on standard CAR shovel test forms.

Site 41BX1272 was identified during the initial north/ south pedestrian survey. Subsequently, east/west transects at 5-m intervals were then walked across the site to identify and document additional surface artifacts. All artifacts observed on the ground surface of 41BX1272 were mapped using a total station, collected, and brought back to the CAR laboratory for analysis and curation.

In addition, raw material was collected from $41 \mathrm{BX} 1272$ to provide a sample with which to compare collected raw material from sites at nearby Lackland AFB. Three-person transects at $15-\mathrm{m}$ intervals were walked from the southern boundary of 41BX1272 until each person had collected 33 chert cobbles for a total sample of 100 . The abundance of chert cobbles dictated that raw material was collected relatively quickly and the length of each transect ended within $20-30 \mathrm{~m}$ from the beginning collection point, or southern boundary of the site.

Photographs were taken using color print film and all photographs were recorded on standard CAR forms. The project area including the unplowed and plowed fields, and site 41BX1272 were mapped using a total station and data collector.

\section{Laboratory Methods}

Cultural lithic material from site $41 \mathrm{BX} 1272$ was brought to the CAR laboratory facility and washed, air-dried, labeled, analyzed, catalogued, and curated. All artifacts, field forms, notes, records, and photographs were curated in archival-quality containers, labeled, inventoried, and placed in CAR's permanent shelving. 


\section{Results}

During the pedestrian survey one archaeological site, 41BX1272, was identified (Figure 4). 41BX1272 is $110 \mathrm{~m}$ north/south by $50 \mathrm{~m}$ east/west (Figure 5). The site is comprised of approximately 60 artifacts including flakes and early and middle stage bifaces, and can be described as a low-density lithic surface scatter. Artifact density is $.0156 \mathrm{per} \mathrm{m}^{2}$. Four shovel tests (STs 1-4) and one backhoe trench (BHT 1) were excavated tain Cretaceous age shark teeth (Houk and Nickels 1997). The stratigraphy observed in BHT 1 was again repeated in STs 1-4. An upper black topsoil extended to a depth of between 35 and $50 \mathrm{~cm}$ bs. Immediately underlying the dark topsoil was the lighter olive brown clay. No cultural material was observed in any of the four shovel tests. These tests indicate that the site is restricted to the surface and that no intact subsurface deposits are present.

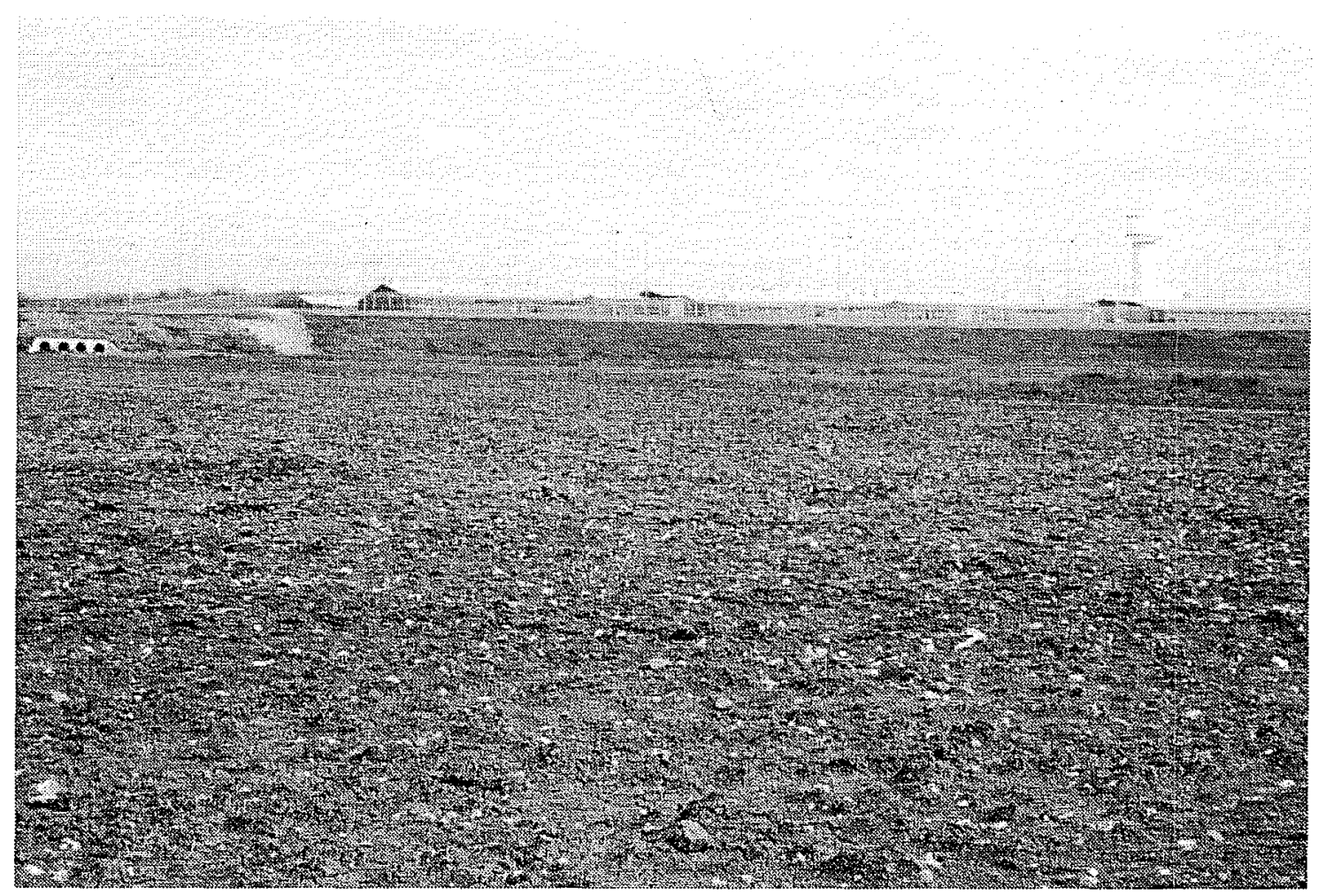

Figure 4. Site $41 B X 1272$ in the project area.

within the site boundary. No cultural material was observed in the STs or the BHT.

The excavation of BHT 1 exposed the soil stratigraphy in the site area (Figure 6). The upper topsoil is composed of a black (7.5YR 2.5/1) clay loam approximately $35 \mathrm{~cm}$ thick. Lying immediately beneath the topsoil is a light olive brown (2.5YR 5/4) clay which extends to a depth of $90 \mathrm{~cm}$ (base of the trench). An abrupt wavy-to-irregular boundary separates the upper topsoil from the lower clay deposit. At Lackland AFB, soil similar to the olive clay was found to con-
BHT 2 was located in a drainage area which is currently inundated from time to time by rainwater originating at, and directed away from the State Correctional Facility to the north. BHT 2 was unique in that the very distinct boundary observed in BHTs $1,3,4$, and 5, did not exist in BHT 2. The profile of BHT 2 showed an upper black (7.5YR 2.5/1) clay loam topsoil, $40 \mathrm{~cm}$ thick, followed by a mottled black (7.5YR 2.5/1) and light olive brown (2.5YR 5/4) clay to a depth of $90 \mathrm{~cm}$ bs. Underlying the mottled soil, the light olive brown clay was found to extend to a depth of $1.5 \mathrm{~m}$ below surface (base of trench) (Figure 7). Aerial photos in the 1962 Bexar County soil sur- 


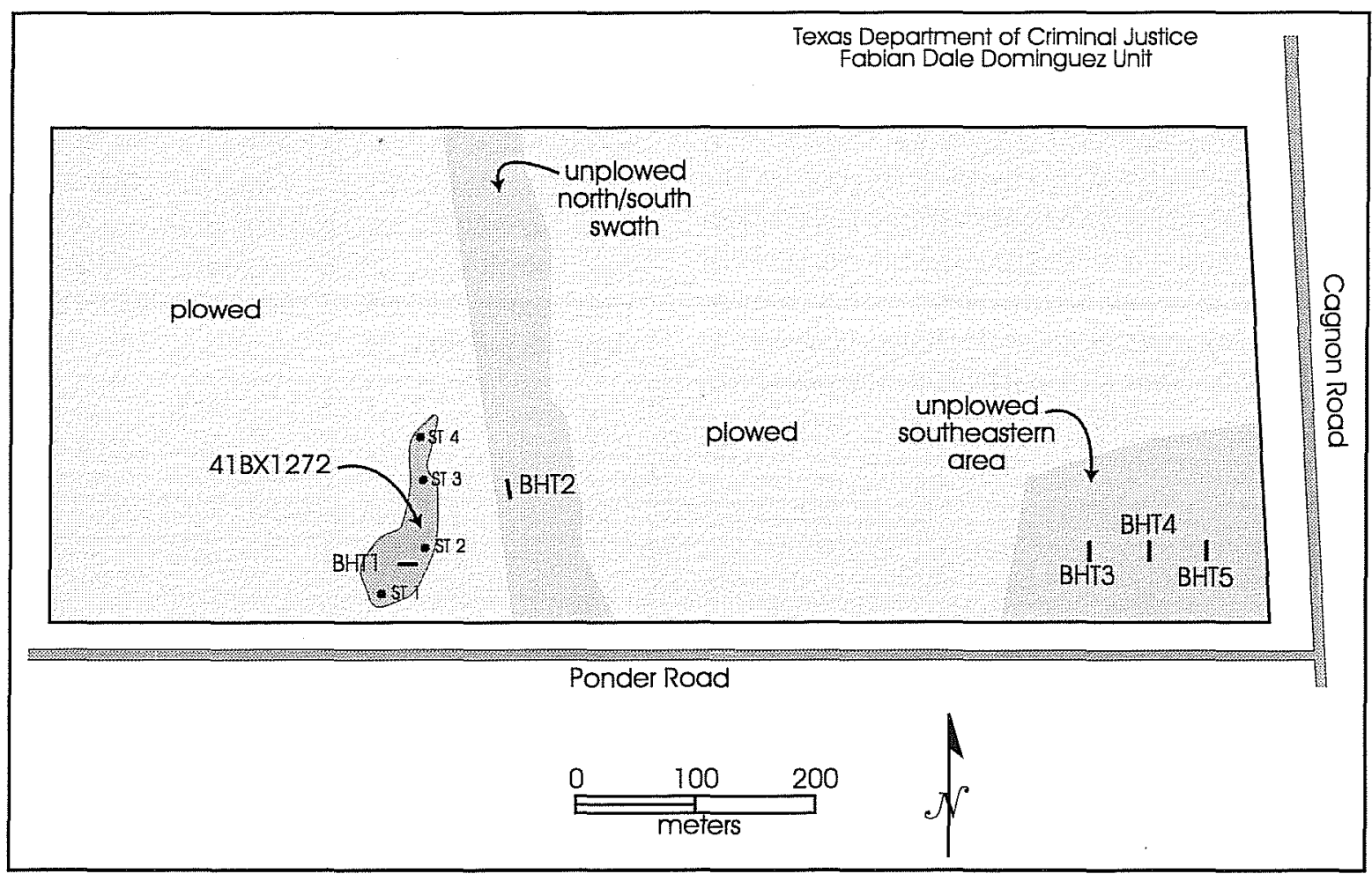

Figure 5. Map showing project boundary, plowed and unplowed fields, site 41BX1272, backhoe trenches, and shovel tests.

vey shows that BHT 2 may have been located in a previous drainage area which led to a stockpond.

BHTs 3, 4, and 5 were evenly distributed in the unplowed field in the southeastern corner of the project area (Figure 5). Since these BHTs were stratigraphically identical, a profile was drawn of only BHT 4 (Figure 8). The upper $35 \mathrm{~cm}$ of topsoil was a black (7.5YR 2.5/1) clay loam, followed by a light olive brown (2.5YR 5/4) clay to a depth of approximately one meter (base of trench). The boundary separating the two soil horizons was very abrupt and very distinct. No cultural material was observed in any of the five backhoe trenches.

General observations made during the pedestrian survey include noting the presence of isolated finds, plow- damaged chert cobbles, fire-cracked chert, Cretaceous age marine megafossils, and land modification presumably as- sociated with agriculture. In addition, much of the eastern and southern sections of the project area experience saturated soil conditions. These areas are presently unplowed due to extremely wet soils.

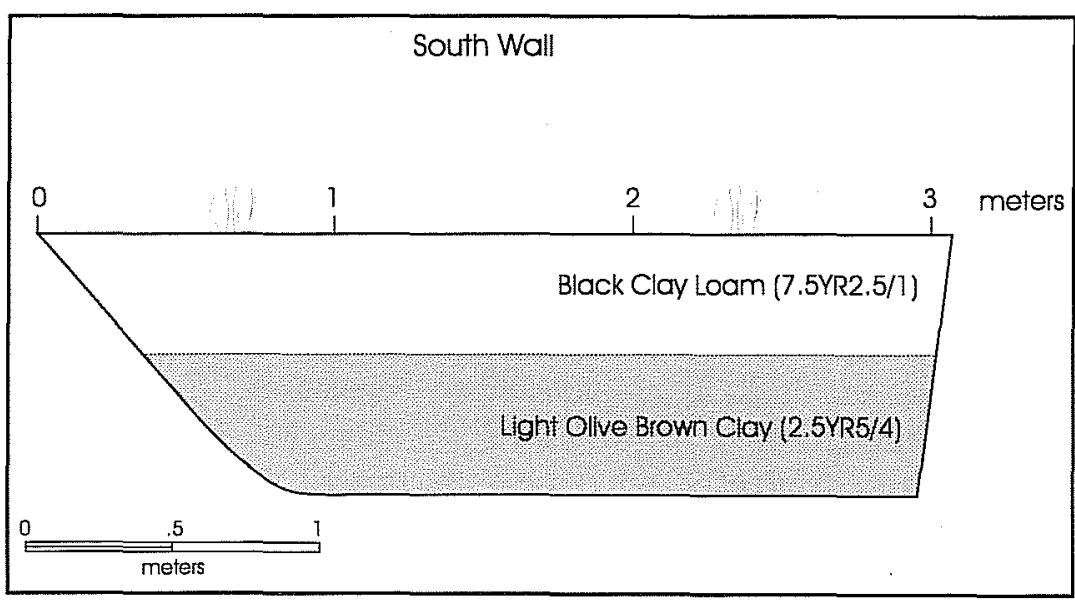

Figure 6. Profile of south wall of BHT 1. 


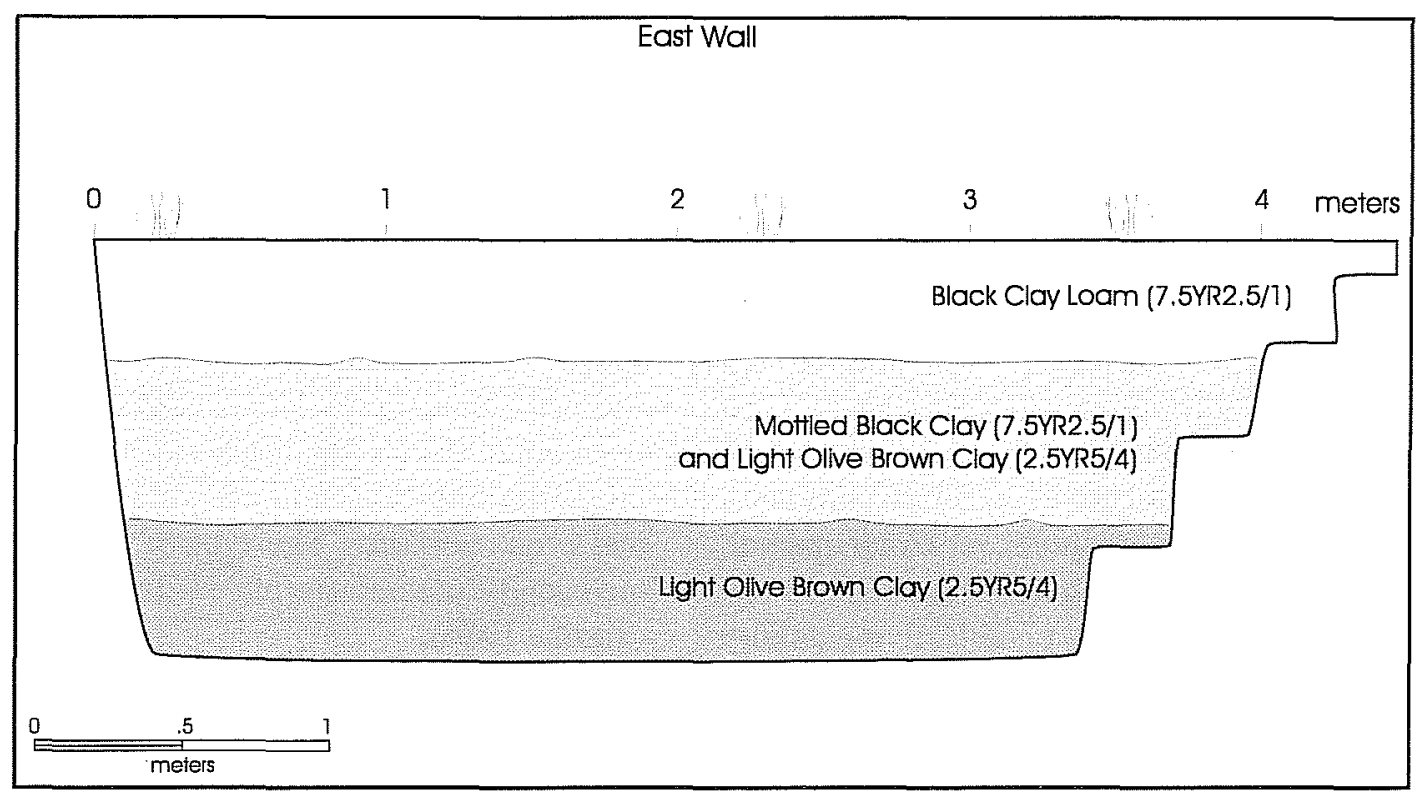

Figure 7. Profile of east wall of BHT 2.

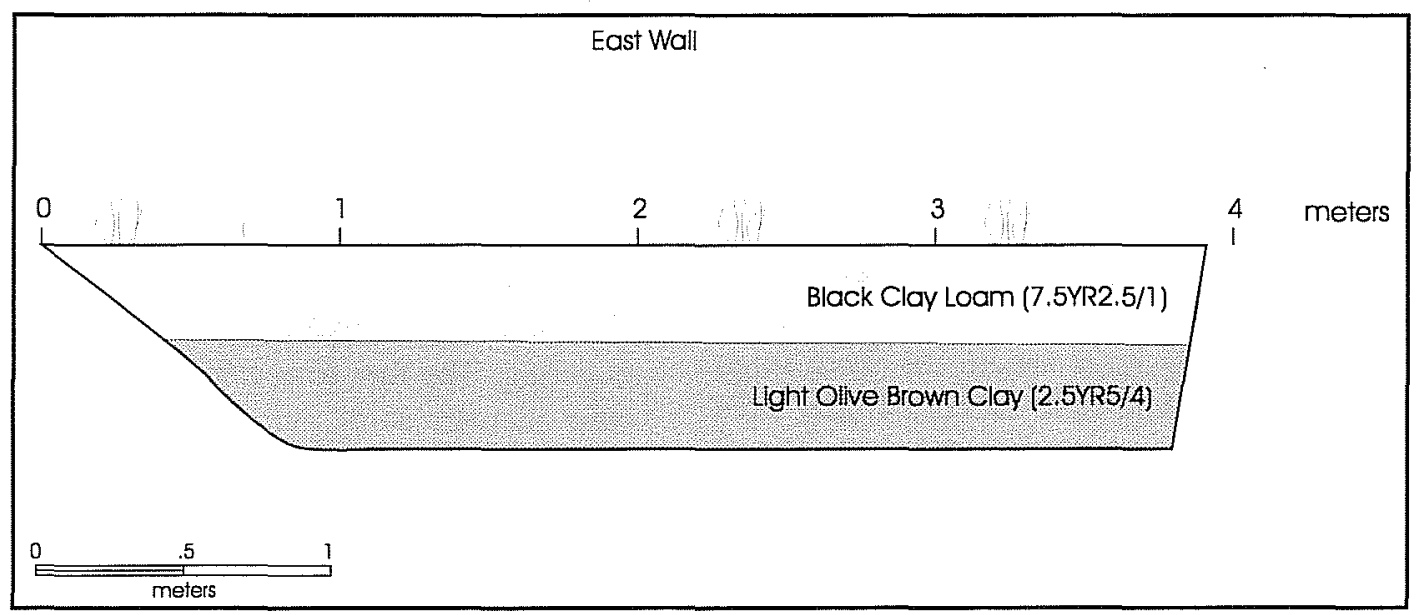

Figure 8. Profile of east wall of BHT 4.

\section{Artifacts}

Sixty chipped stone artifacts were recovered during a 100 -percent surface collection of $41 B X 1272$. The lithic material includes one projectile point preform, 16 bifaces, six cores (four whole cores and two fragments), one cobble tool, two unifaces, and 34 pieces of debitage. Twelve of the bifaces are identified as early-stage, and four as middle-stage reduction bifaces. Of the debitage, 14 are complete flakes, and the remaining 20 are incomplete flakes.

In order to provide a means for comparing the lithic material of site $41 \mathrm{BX} 1272$ with nearby sites at
Lackland AFB, the same artifact classes were constructed, and the same artifact attributes were analyzed (Houk and Nickels 1997). Appendix A provides the raw data for artifacts from 41BX1272.

\section{Bifaces}

Artifacts that have been flaked on both sides of the same lateral edge are classified as bifaces. The only exception to this is bidirectional cores. Sixteen bifaces was recovered during the surface collection of 41BX1272. For each specimen, the following at- 
tributes were recorded: raw material type, raw material quality, burning, percentage of cortex remaining, length, width, thickness, tool completeness, blank type, and evidence for tool recycling. Burning was coded as either being present or absent and was determined by the presence of crazing, heat fractures, or pot lids. The percentage of cortex remaining on each biface was estimated as a percentage of the total surface area of both faces and was coded as either absent, 1-50 percent, or 51-99 percent. Length, width, and thickness were measured to the millimeter. Tool completeness was coded as either complete, proximal, medial, distal, longitudinal, wedge, or indeterminate. The stage of reduction of a biface was a subjective category coded as either early, middle, late, or indeterminate. To insure consistency, all bifaces were coded by the same laboratory analyst.

Early-stage bifaces usually retain a small to large amount of cortex and have relatively few flake removals, all of which were removed by hard-hammer percussion. The edges of these bifaces are generally very sinuous when viewed in profile. Middle-stage reduction bifaces are typically thinner than early-stage bifaces, have little or no cortex remaining, and have numerous flake scars, many of which may travel beyond the midline of the biface. The edges are less sinuous than those of early-stage specimens. Late-stage reduction bifaces are thin, have no cortex, and have numerous flake scars. Most of the flakes from late stage reduction are removed by billet or soft-hammer percussion. Flake scars are, therefore, relatively longer and shallower than in early-stage reduction. The edges of late stage bifaces are usually straight when viewed in profile. If a specimen was too fragmentary to determine its position in the reduction model, it was classified as indeterminate.

Biface shape, or outline, was coded as either ovate, pointed-ovate, triangular, or indeterminate. The pointed-ovate form is characterized by a rounded, or convex, base and pointed blade. A triangular biface has a pointed blade and a straight base.

Incomplete bifaces were identified as to break type. The only break type observed on bifaces from 41BX1272 was the manufacture break. Manufacture breaks typically result from either lateral biface thin- ning failures or basal thinning failures (Tomka 1986). A common break type associated with lateral biface thinning failures is known as a perverse fracture. Defined by Crabtree (1972:82) as "helical, spiral or twisting break initiated at the edge of an objective piece," perverse fractures are easily identified by the twisting of the fracture plane on a rotational axis that corresponds to the direction of the force that initiated the fracture. The other type of manufacture break observed resulted in what is identified as a wedge. Wedges are triangular fragments with one bifacially worked edge and two break faces. This type of fragment is characteristically created during biface thinning failures (Tomka 1986).

\section{Unifaces}

Artifacts that had been flaked on one surface are classified as unifaces. The only exception to this is unidirectional cores. Two unifaces were recovered during the surface collection of site 41BX1272. For each specimen, the following attributes were recorded: raw material type, raw material quality, burning, percentage of cortex remaining, maximum dimension, blank type, tool completeness, degree of retouch, location of modification, edge shape, and evidence for tool recycling. The first four attributes were coded in the same manner as described above for bifaces. The maximum dimension of each uniface was measured to the nearest millimeter. Blank type was recorded as either flake, blade, other, or indeterminate. Tool completeness was coded in the same manner as for bifaces, although the wedge classification was not used. The degree of retouch for unifaces is a somewhat subjective category. The possible classifications are expedient, minimal, formal, and indeterminate. Expedient unifaces are flakes that have been modified through use but not by intentional flaking or shaping. Minimally retouched unifaces, however, have not been drastically altered from their original form, but some flaking has been used to alter the shape of one or more edge. Formal unifaces include artifacts commonly called scrapers, gouges, or unifacial knives, inferring functional usage. One or more edge has been significantly shaped through the deliberate patterning of flake removals. 


\section{Cores}

Four whole cores and two core fragments were recovered during the surface collection of site 41BX1272. For each whole specimen, the following attributes were recorded: raw material type, raw material quality, evidence of burning, percentage of cortex remaining, maximum dimension, number of flake scars, and flake scar direction. The first four attributes were coded in the manner described above for bifaces and unifaces. The maximum dimension was measured to the nearest centimeter. Flake count excluded small hinge and step fractures resulting from efforts to prepare striking platforms. Flake direction was classified as either unidirectional, bidirectional, multiple, or indeterminate.

\section{Unmodified Debitage}

Thirty-four pieces of debitage were collected from site 41BX1272. Twenty of these represent incomplete flakes and 14 are complete flakes. Only the latter were analyzed using an approach in which each is assigned to a predefined flake type. Following the analysis of the Lackland lithic material, flakes were assigned to a specific flake type based on a list of attributes that are most characteristic of specific reduction technologies (Houk and Nickels 1997). Complete flakes are defined as those with intact platforms and a measurable maximum length. For each complete flake the following attributes were recorded: raw material type, raw material quality, maximum dimension (rounded up to nearest centimeter), platform faceting, amount of dorsal cortex, and flake type. Platform faceting was characterized as either single, double, multiple $(3+)$, or corticate. The amount of dorsal cortex was quantified as either 100 percent (primary flake), less than 100 percent but greater than 0 percent (secondary flake), or 0 percent (tertiary flake) of the surface area of the dorsal side of the flake. Flake types recognized in the current assemblage included biface manufacture, platform preparations and/or core preparation, and indeterminates.

\section{Biface Manufacture Flakes}

These flakes are defined as primary and secondary flakes having moderate to large dorsal flake scar ridges and with minimal to considerable longitudinal curvature. The striking platforms on this type range from single to multifaceted, although single and double faceting is most common. These flakes are usually removed with a hard hammerstone or large billet, and the dorsal flake scarring is indicative of sequential flake removals and flake removals from opposite edges (Mehalchick et al. 1996).

\section{Platform Preparation and/or Core Preparation Flakes}

Platform and core preparation flakes are highly variable in size, shape, amount of dorsal cortex, and platform faceting, but they all represent an attempt to prepare a platform or core for subsequent flake removals. Size and platform faceting are dependent upon the stage of reduction during which they were removed and the size of the parent material which may be a core or artifact. Likewise, shape is dependent on the type of core from which they were removed. The amount of dorsal cortex is also highly variable, ranging from 0 to 100 percent, depending on the stage of reduction (Mehalchick et al. 1996).

\section{Indeterminate Flakes}

If a flake could not be assigned with certainty, it was coded as indeterminate. Generally, flakes displaying attributes associated with two or more different types were included in the indeterminate category.

\section{Discussion}

Four shovel tests and one backhoe trench excavated within the boundaries of site $41 \mathrm{BX} 1272$ did not produce evidence of subsurface artifacts. It is possible that small flakes may exist below the surface, however, none were observed. A 100-percent surface col- 
Table 1. Contingency Table Analysis of Number of Artifacts by Category at Each Site.

Top value in cell represents artifact count, middle value is row percent, and bottom value represents adjusted residuals. Percent value in total column represents column percent. Percent value in row total represents total artifact count and percent by site. Significant $(p<0.05)$ values are shown in bold.

\begin{tabular}{|c|c|c|c|c|c|}
\hline Site & Cores & Bifaces & $\begin{array}{l}\text { Projectile } \\
\text { Points }\end{array}$ & Unifaces & Row Total \\
\hline $41 \mathrm{BX} 1272$ & $\begin{array}{c}4 \\
17.4 \% \\
-4.3\end{array}$ & $\begin{array}{c}16 \\
69.6 \% \\
\mathbf{5 . 8}\end{array}$ & $\begin{array}{c}1 \\
4.3 \% \\
1.2\end{array}$ & $\begin{array}{c}2 \\
8.7 \% \\
-1.0\end{array}$ & $\begin{array}{l}23 \\
.6 \%\end{array}$ \\
\hline $41 \mathrm{~B} \times 1090$ & $\begin{array}{c}133 \\
89.9 \% \\
7.3\end{array}$ & $\begin{array}{c}10 \\
6.8 \% \\
-4.3\end{array}$ & $\begin{array}{c}0 \\
0.0 \% \\
-1.5\end{array}$ & $\begin{array}{c}5 \\
3.4 \% \\
-4.4\end{array}$ & $\begin{array}{c}148 \\
3.9 \%\end{array}$ \\
\hline $41 \mathrm{~B} \times 1091$ & $\begin{array}{c}409 \\
89.9 \% \\
\mathbf{1 3 . 4}\end{array}$ & $\begin{array}{c}25 \\
5.5 \% \\
\mathbf{- 8 . 6}\end{array}$ & $\begin{array}{c}2 \\
.4 \% \\
-1.8\end{array}$ & $\begin{array}{c}19 \\
4.2 \% \\
-7.6\end{array}$ & $\begin{array}{c}455 \\
12.1 \%\end{array}$ \\
\hline $41 \mathrm{~B} \times 1088$ & $\begin{array}{c}1010 \\
67.4 \% \\
6.5\end{array}$ & $\begin{array}{c}339 \\
22.6 \% \\
2.1\end{array}$ & $\begin{array}{c}17 \\
1.1 \% \\
-1.1\end{array}$ & $\begin{array}{c}132 \\
8.8 \% \\
\mathbf{- 1 0 . 4}\end{array}$ & $\begin{array}{c}1498 \\
39.9 \%\end{array}$ \\
\hline $41 \mathrm{BX} 1076$ & $\begin{array}{c}221 \\
57.1 \% \\
-1.7\end{array}$ & $\begin{array}{c}104 \\
26.9 \% \\
\mathbf{3 . 0}\end{array}$ & $\begin{array}{c}2 \\
.5 \% \\
-1.5\end{array}$ & $\begin{array}{c}60 \\
15.5 \% \\
-.6 \\
\end{array}$ & $\begin{array}{c}387 \\
10.3 \%\end{array}$ \\
\hline $41 \mathrm{BX} 1114$ & $\begin{array}{c}320 \\
52.6 \% \\
-4.7\end{array}$ & $\begin{array}{c}98 \\
16.1 \% \\
\mathbf{- 3 . 2}\end{array}$ & $\begin{array}{c}7 \\
1.2 \% \\
-.5\end{array}$ & $\begin{array}{c}183 \\
30.1 \% \\
9.8\end{array}$ & $\begin{array}{c}608 \\
16.2 \%\end{array}$ \\
\hline $41 \mathrm{~B} X 1103$ & $\begin{array}{c}51 \\
14.5 \% \\
\mathbf{- 1 8 . 8}\end{array}$ & $\begin{array}{c}116 \\
33.0 \% \\
\mathbf{5 . 9}\end{array}$ & $\begin{array}{c}11 \\
3.1 \% \\
2.9\end{array}$ & $\begin{array}{c}173 \\
49.3 \% \\
17.3\end{array}$ & $\begin{array}{c}351 \\
9.3 \%\end{array}$ \\
\hline $41 \mathrm{~B} \times 1102$ & $\begin{array}{c}149 \\
51.6 \% \\
\mathbf{- 3 . 5}\end{array}$ & $\begin{array}{c}78 \\
27.0 \% \\
\mathbf{2 . 6}\end{array}$ & $\begin{array}{c}12 \\
4.2 \% \\
4.2\end{array}$ & $\begin{array}{c}50 \\
17.3 \% \\
.3\end{array}$ & $\begin{array}{c}289 \\
7.7 \%\end{array}$ \\
\hline $\begin{array}{l}\text { Column } \\
\text { Total }\end{array}$ & $\begin{array}{c}2297 \\
61.1 \%\end{array}$ & $\begin{array}{c}786 \\
20.9 \%\end{array}$ & $\begin{array}{c}52 \\
1.4 \%\end{array}$ & $\begin{array}{c}624 \\
16.6 \%\end{array}$ & $\begin{array}{c}3759 \\
100.0 \%\end{array}$ \\
\hline
\end{tabular}

Chi-Square $=812.68889(\mathrm{DF}=21)$

lection of visible artifacts was conducted at 41BX1272. Since the collection of surface artifacts has limitations - mainly, that only visible artifacts are recovered - a certain bias may be introduced into the artifact assemblage. It is obvious that small lithic material, such as thinning, pressure, and resharpening flakes, were not recovered to the same degree as larger, more visible artifacts. Nevertheless, the artifact assemblage can provide important information to site interpretation, and it is assumed for the discussion presented below that a representative sample of worked artifacts, not flakes, was recovered.

The lithic assemblage from 41BX1272 shows a greater representation of bifaces (69.6 percent), compared to cores (17.4 percent), projectile points (4.3 percent), and unifaces ( 4.3 percent) (Table 1$)$. Only one projectile point, a Pedernales preform, was recovered from the site. Four complete cores, and two core fragments were collected. The complete cores are all multidi- 
rectional and their maximum dimension ranges between 6.5 and $11 \mathrm{~cm}$. They have between 5 and 9 flake scars and all retain cortex between 1 and 50 percent. Both early- (12) and middle-stage (4) bifaces were collected. Fourteen of the bifaces recovered from $41 \mathrm{BX} 1272$ are complete and two have manufacturing breaks. Thirty- four pieces of debitage were recovered. Of complete flakes, biface manufacturing and platform/core preparation flakes dominate the assemblage (Appendix A). Complete flakes include two primary, 11 secondary, and one tertiary flakes. The majority of complete flakes range in size from 5 to 9 $\mathrm{cm}$.

When chipped stone (excluding debitage) from $41 \mathrm{BX} 1272$ is compared to chipped stone recovered from archaeological sites located at nearby Lackland $\mathrm{AFB}$, it is evident that the assemblage from 41BX 1272 represents a different site type than those found at Lackland (see adjusted residual scores, Table 1). Adjusted residuals greater than 1.96 or less than -1.96 are significant at the .05 level (Haberman 1973). Sites from Lackland AFB (excluding 41BX1103) are dominated by a high percentage of cores, ranging from 51.6 percent to 89.9 percent (Table 1).

A visual inspection of the project area and a review of the Macdona Quadrangle Map indicate some degree of land modification. Mike Fulgham (personal communication 1998), backhoe operator from Wrightway Backhoe Service and long-time resident of the area, informed us that it is a common agricultural practice to scrape the topsoil from a sloping area, level the subsoil, and redistribute the topsoil across the leveled field.

The Lackland sites of 41BX1090, 41BX1091 and 41BX1088 are lithic procurement sites characterized by a higher-than-expected frequency of cores and a lower-than-expected frequency of bifaces and unifaces (Table 1). These sites represent initial reduction of nodular cores in the production of flake blanks. Comparatively, site $41 \mathrm{BX} 1272$ is characterized by an overrepresentation of bifaces and an under-representation of cores. Site 41BX1272 reflects the activities of earlystage biface production (Table 1). The Lackland sites of 41BX1076 and 41BX1114 are both open campsites with abundant raw material. While $41 \mathrm{BX} 1076$ has a higher-than-expected frequency of bifaces (Table 1), it has an expected frequency of cores, projectile points, and unifaces; as well as scattered burned rock and concentrated accumulations of burned rock, all of which suggest it functioned as a campsite. Site 41BX1114 is characterized by a lower-than-expected frequency of both bifaces and cores, and a higher-thanexpected frequency of unifaces, and yielded eight Leon Plain ceramic sherds (Houk and Nickels 1997).

Residential camp sites 41BX1102 and 41BX1103 are similar to $41 \mathrm{BX} 1272$ in that they have both an overrepresentation of bifaces and an under-representation of cores (Table 1). However, these residential sites also have higher-than-expected frequencies of projectile points, and site $41 \mathrm{BX} 1103$ has a higher-than-expected frequency of unifaces (Table 1). In addition to worked lithic material, burned rock was observed in varying quantities at sites $41 \mathrm{BX} 1102$ and $41 \mathrm{BX} 1103$. The analysis of artifacts from $41 \mathrm{BX} 1102$ indicates that this site represents late-stage reduction activities (Houk and Nickels 1997). In addition to lithic material, site 41BX1103 yielded faunal remains and burned rock. Unlike the Lackland residential sites, burned rock (limestone) was not observed at 41BX1272 and firecracked chert was only minimally represented across the project area.

The artifact assemblage (early- and middle-stage bifaces, and biface manufacturing and platform/core preparation flakes) suggests that 41BX1272 represents a lithic procurement site where activities focused on the production of early-stage bifaces. Chert cobbles, approximately $10 \mathrm{~cm}$ in diameter, are numerous across the project area. The absence of hearth features, burned rock, and faunal remains further suggest that 41BX1272 does not represent a campsite, and the lower than expected frequencies of cores suggests that this site does not reflect the activities associated with the reduction of nodular cores for the production of flake blanks.

\section{Summary and Recommendations}

One archaeological site, 41BX1272, was identified during the current investigation. A comparative study employing contingency table and adjusted residual 
analysis of chipped stone artifacts recovered from $41 \mathrm{BX} 1272$ with those recovered from other sites located at nearby Lackland AFB indicates that $41 \mathrm{BX} 1272$ represents a site type not found at Lackland. $41 \mathrm{BX} 1272$ is characterized by a higherthan-expected frequency of bifaces and a lower-thanexpected frequency of cores and thus represents a lithic procurement site reflecting the activities associated with early-stage biface production.

The archaeological site (41BX1272) identified during the current project is restricted to the surface and exists within a disturbed context. Given the thin topsoil observed across the project area, Cretaceous age subsoil, past and present agricultural activities, and land modifications like the one described above, these upland soils do not have the potential for containing buried cultural materials in a primary context. Therefore, we recommend that no further archaeological work is required prior to the construction of the Bexar County Correctional Facility. 


\section{References Cited}

Bannon, J. F.

1979 The Spanish Borderlands Frontier 1513-1821. University of New Mexico Press, Albuquerque.

Barnes, V. E.

1983 Geologic Atlas of Texas: San Antonio Sheet. Bureau of Economic Geology, The University of Texas at Austin.

Black, S. L.

1989a Environmental Setting. In From the Gulf Coast to the Rio Grande: Human Adaptation in the Central, South, and Lower Pecos Texas, edited by T. R. Hester, S. L. Black, D. G. Steele, B. W. Olive, A. A. Fox, K. J. Reinhard, and L. C. Bement, pp. 5-16. Research Series No. 33. Arkansas Archeological Survey, Fayetteville.

1989b Central Texas Plateau Prairie. In From the Gulf Coast to the Rio Grande: Human Adaptation in Central, South and Lower Pecos Texas, edited by T. R. Hester, S.L. Black, D. G. Steele, B. W. Olive, A. A. Fox, K. J. Reinhard, and L. C. Bement, pp. 17-38. Research Series No. 33. Arkansas Archeological Survey, Fayetteville.

1989c South Texas Plain. In From the Gulf Coast to the Rio Grande: Human Adaptation in Central, South and Lower Pecos Texas, edited by T. R. Hester, S. L. Black, D. G. Steele, B. W. Olive, A. A. Fox, K. J. Reinhard, and L. C. Bement, pp. 39-62. Research Series No. 33. Arkansas Archeological Survey, Fayetteville.

Blair, W. F.

1950 The Biotic Provinces of Texas. The Texas Journal of Science 2(1):93-117.

Bruseth, J. E.

1992 Artifacts of the De Soto Expedition: The Evidence from Texas. Bulletin of the Texas Archeological Society 63:67-97.

Collins, M. B., and R. A. Ricklis

1994 Cultural Background. In Archaic and Late Prehistoric Human Ecology in the Middle Onion Creek Valley, Hays County, Texas, edited by M. B. Collins and R. A. Ricklis, 1:11-26. Studies in Archeology 19. Texas Archeological Research Laboratory, The University of Texas at Austin.

Collins, M. B.

1995 Forty Years of Archeology in Central Texas. Bulletin of the Texas Archeological Society 66:361-400.

Haberman, S. J.

1973 The Analysis of Residuals in Cross-Classified Tables. Biometrics 29:205-220.

Houk, B. A., and D. L. Nickels

1997 Phase II Archaeological Investigations at Lackland Air Force Base, San Antonio, Texas. Archaeological Survey Report, No. 264. Center for Archaeological Research, The University of Texas at San Antonio.

McGraw, A. J., and K. Hindes

1987 Chipped Stone and Adobe: A Cultural Resources Assessment of the Proposed Applewhite Reservoir, Bexar County, Texas. Archaeological Survey Report, No. 163. Center for Archaeological Research, The University of Texas at San Antonio. 
Nickels, D., D. W. Pease, and C. Britt Bousman

1997 Archaeological Survey of Lackland Air Force Base, Bexar County, Texas. Archaeological Survey Report, No. 248. Center for Archaeological Research, The University of Texas at San Antonio.

Nickels, D., C. Horrell, G. T. Bernhardt, P. W. McWhorter, and L. C. Nordt

1998 An Archaeological Survey of a Pipeline Right-of-Way along Loop 1604 from IH-37 to the San Antonio River, Southeast Bexar County, Texas. Archaeological Survey Report, No. 273. Center for Archaeological Research, The University of Texas at San Antonio.

Potter, D. R.

1990 Archaeological Survey of the Covel Gardens Landfill Area in San Antonio, Bexar County, Texas. Archaeological Survey Report, No. 202. Center for Archaeological Research, The University of Texas at San Antonio.

Ricklis, R. A.

1994 Toyah Components: Evidence For Occupation in the Project Area During the Latter Part of the Late Prehistoric Period. In Archaic and Late Prehistoric Human Ecology in the Middle Onion Creek Valley, Hays County, Texas, edited by M. B. Collins and R. A. Ricklis, 1:207-315. Studies in Archeology 19. Texas Archeological Research Laboratory, The University of Texas at Austin.

Taylor, F. B., R. B. Hailey, and D. L. Richmond

1991 Soil Survey of Bexar County, Texas. Soil Conservation Service, U.S. Department of Agriculture, Washington D.C.

Tennis, C. L.

1996 Archaic Land Use of Upper Leon Creek Terraces: Archaeological Testing in Northern Bexar County, Texas. Archaeological Survey Report, No. 234. Center for Archaeological Research, The University of Texas at San Antonio.

Trierweiler, W. N., G. L. Ellis, and J. M. Quigg

1995 Research Context for Site Testing. In NRHP Significance Testing of 57 Prehistoric Archaeological Sites on Fort Hood, Texas. Archaeological Resource Management Series Research Report No. 34. Vol 1:27-38. United States Army, Fort Hood.

Ricklis, R. A., and M. B. Collins

1994 The Environmental Context. In Archaic and Late Prehistoric Human Ecology in the Middle Onion Creek Valley, Hays County, Texas, edited by M. B. Collins and R. A. Ricklis, 1:27-36. Studies in Archeology 19. Texas Archeological Research Laboratory, The University of Texas at Austin.

Weir, F. A.

1976 The Central Texas Archaic. Unpublished Ph.D. dissertation. Washington State University, Pullman. 


\section{Appendix A: Artifact Data, Site 41BX1272}

Table A-1. Biface Data, Site 41BX1272

\begin{tabular}{|c|c|c|c|c|c|c|c|c|c|c|c|c|c|}
\hline $\begin{array}{l}\text { Surface } \\
\text { Coll. \# }\end{array}$ & $\begin{array}{l}\text { Mat. } \\
\text { Type }\end{array}$ & $\begin{array}{c}\text { Grain Size } \\
\text { (Inclusions?) }\end{array}$ & Burn? & $\% \mathrm{Crt}$ & \multicolumn{3}{|c|}{ Dimensions (mm) } & Tool Comp & Blank Type & $\begin{array}{c}\text { Reduc } \\
\text { Stage } \\
\end{array}$ & Shape & $\begin{array}{l}\text { Break } \\
\text { Type }\end{array}$ & $\begin{array}{c}\text { Tool } \\
\text { Recycle? }\end{array}$ \\
\hline & & & & & $\mathrm{L}$ & $\mathrm{w}$ & Th & & & & & & \\
\hline 2 & chert & fine (ves) & no & $1-50$ & 75 & 52 & 39 & complete & nodule & early & ovate & $n / a$ & no \\
\hline 4 & chert & fine (no) & no & 51-99 & 145 & 74 & 40 & complete & nodule & early & ovate & $n / a$ & no \\
\hline 15 & chert & fine (yes) & no & $1-50$ & 65 & 66 & 21 & distal & nodule & early & ovate & manufact & no \\
\hline 20 & chert & fine (yes) & no & absent & 83 & 47 & 24 & complete & indeterm & middle & ovate & $\mathrm{n} / \mathrm{a}$ & no \\
\hline 24 & chert & fine (no) & no & absent & 47 & 30 & 15 & wedge & indeterm & middle & ovate & manufact & no \\
\hline 29 & chert & fine (yes) & no & absent & 61 & 47 & 22 & complete & indeterm & middle & ovate & $n / a$ & no \\
\hline 30 & chert & fine (no) & no & $1-50$ & 89 & 63 & 34 & complete & nodule & early & pointed-ovate & n/a & no \\
\hline 34 & chert & fine (no) & no & $1-50$ & 69 & 57 & 36 & complete & nodule & early & ovate & n/a & no \\
\hline 36 & chert & fine (yes) & no & $1-50$ & 92 & 79 & 40 & complete & nodule & early & ovate & $\mathrm{n} / \mathrm{a}$ & no \\
\hline 41 & chert & fine (no) & yes & $1-50$ & 73 & 61 & 23 & complete & nodule & early & ovate & n/a & no \\
\hline 44 & chert & fine (no) & no & $1-50$ & 82 & 57 & 32 & complete & indeterm & early & ovate & n/a & no \\
\hline 45 & chert & fine (yes) & yes & $1-50$ & 68 & 37 & 27 & complete & nodule & early & ovate & n/a & no \\
\hline 47 & chert & fine (ves) & no & absent & 72 & 50 & 20 & complete & indeterm & middle & pointed-ovate & n/a & no \\
\hline 50 & chert & fine (ves) & no & $1-50$ & 107 & 69 & 57 & complete & indeterm & early & ovate & n/a & no \\
\hline 51 & chert & fine (no) & no & $1-50$ & 82 & 53 & 29 & complete & nodule & early & ovate & $\mathrm{n} / \mathrm{a}$ & no \\
\hline 58 & chert & fine (yes) & yes & $51-99$ & 101 & 73 & 46 & complete & nodule & early & ovate & n/a & \\
\hline
\end{tabular}

Table A-2. Uniface Data, Site 41BX1272

\begin{tabular}{|c|c|c|c|c|c|c|l|l|l|c|c|}
\hline $\begin{array}{c}\text { Bag } \\
\#\end{array}$ & $\begin{array}{c}\text { Mat. } \\
\text { Type }\end{array}$ & $\begin{array}{c}\text { Grain Size } \\
\text { (Inclusions?) }\end{array}$ & Burn? & $\begin{array}{c}\text { Max. Dimen. } \\
(\mathbf{m m})\end{array}$ & $\begin{array}{c}\% \\
\text { Cortex }\end{array}$ & $\begin{array}{c}\text { Degree } \\
\text { Retouch }\end{array}$ & Tool Comp. & $\begin{array}{c}\text { Blank } \\
\text { Type }\end{array}$ & $\begin{array}{c}\text { Loc. of } \\
\text { Modif. }\end{array}$ & $\begin{array}{c}\text { Edge } \\
\text { Shape }\end{array}$ & $\begin{array}{c}\text { Tool } \\
\text { Recycle? }\end{array}$ \\
\hline 14 & chert & fine (yes) & no & 27 & $1-50$ & expedient & complete & flake & lateral and distal & convex & no \\
\hline 46 & chert & coarse & no & 68 & $1-50$ & minimal & complete & flake & multiple & multiple & no \\
\hline
\end{tabular}

Table A-3. Projectile Point Attributes, Site 41BX1272

\begin{tabular}{|c|c|c|c|c|c|c|}
\hline Bag \# & $\begin{array}{c}\text { Mat. } \\
\text { Type }\end{array}$ & $\begin{array}{c}\text { Grain Size } \\
\text { (Inclusions?) }\end{array}$ & Burn? & $\begin{array}{c}\text { Proj. } \\
\text { SubGroup }\end{array}$ & Proj. Type & Serr. \\
\hline 17 & chert & fine (no) & no & DP preform & Pedernales & absent \\
\hline
\end{tabular}

\begin{tabular}{|c|c|c|c|c|c|c|c|c|c|}
\hline Bevel & Compl. & Break & $\begin{array}{c}\text { Max. } \\
\text { Length }\end{array}$ & $\begin{array}{c}\text { Blade } \\
\text { Length }\end{array}$ & $\begin{array}{c}\text { Blade } \\
\text { Width }\end{array}$ & $\begin{array}{c}\text { Haft } \\
\text { Length }\end{array}$ & $\begin{array}{c}\text { Neck } \\
\text { Width }\end{array}$ & $\begin{array}{c}\text { Base } \\
\text { Width }\end{array}$ & $\begin{array}{c}\text { Max. } \\
\text { Thick. }\end{array}$ \\
\hline absent & proximal & indeterm. & n/a & n/a & n/a & indeterm & indeterm & indeterm & $7 \mathrm{~mm}$ \\
\hline
\end{tabular}


Table A-4. Debitage Data, Site 41BX1272

\begin{tabular}{|c|c|l|l|c|l|l|l|}
\hline Bag \# & $\begin{array}{c}\text { Mat. } \\
\text { Type }\end{array}$ & $\begin{array}{c}\text { Internal } \\
\text { Fracture }\end{array}$ & $\begin{array}{c}\text { Grain Size } \\
\text { (Inclusions?) }\end{array}$ & $\begin{array}{c}\text { Maximum } \\
\text { Dimensions (cm) }\end{array}$ & $\begin{array}{l}\text { Platform } \\
\text { Faceting }\end{array}$ & $\begin{array}{c}\text { Dorsal } \\
\text { Cortex }\end{array}$ & \multicolumn{1}{|c|}{ Flake Type } \\
\hline $39-1$ & chert & absent & fine (yes) & $5-6$ & corticate & primary & biface manuf \\
\hline 1 & chert & absent & fine (no) & $5-6$ & single & secondary & biface manuf \\
\hline 32 & chert & absent & fine (yes) & $5-6$ & three + & secondary & biface manuf \\
\hline 7 & chert & absent & fine (yes) & $5-6$ & three + & secondary & biface manuf \\
\hline 19 & chert & absent & fine (no) & $8-9$ & corticate & secondary & biface manuf \\
\hline 43 & chert & absent & fine (no) & $3-4$ & single & secondary & platform/core prep \\
\hline 41 & chert & absent & fine (yes) & $3-4$ & single & secondary & platform/core prep \\
\hline $37-2$ & chert & absent & fine (no) & $4-5$ & single & secondary & platform/core prep \\
\hline $35-1$ & chert & absent & fine (no) & $5-6$ & single & secondary & platform/core prep \\
\hline 9 & chert & absent & fine (no) & $2-3$ & double & secondary & platform/core prep \\
\hline 56 & chert & absent & fine (no) & $6-7$ & corticate & secondary & platform/core prep \\
\hline $35-2$ & chert & absent & fine (yes) & $6-7$ & corticate & secondary & platform/core prep \\
\hline $37-1$ & chert & absent & fine (no) & $1-2$ & single & tertiary & platform/core prep \\
\hline 25 & chert & absent & fine (no) & $4-5$ & corticate & primary & indeterminate \\
\hline
\end{tabular}

Table A-5. Core Data, Site 41BX1272

\begin{tabular}{|c|l|l|c|c|c|c|c|c|}
\hline $\begin{array}{c}\text { Surface } \\
\text { Collection \# }\end{array}$ & $\begin{array}{c}\text { Mat. } \\
\text { Type }\end{array}$ & $\begin{array}{c}\text { Grain Size } \\
\text { (Inclusons?) }\end{array}$ & Burn? & $\begin{array}{r}\text { Maximum } \\
\text { Dimension (cm) }\end{array}$ & $\begin{array}{c}\text { \% Dorsal } \\
\text { Cortex }\end{array}$ & $\begin{array}{c}\text { \# of Flake } \\
\text { Scars }\end{array}$ & $\begin{array}{c}\text { Flake } \\
\text { Direction }\end{array}$ & $\begin{array}{c}\text { Tool } \\
\text { Recycle? }\end{array}$ \\
\hline 10 & chert & fine (yes) & yes & 7 & $1-50$ & 9 & indet & no \\
\hline 11 & chert & fine (yes) & no & 6.5 & $1-50$ & 5 & multi & no \\
\hline 22 & chert & fine (no) & no & 8.5 & $1-50$ & 5 & multi & no \\
\hline 54 & chert & fine (no) & no & 11 & $1-50$ & 9 & multi & no \\
\hline
\end{tabular}


Table A-6. Assemblage Data, Site 41BX1272

\begin{tabular}{|c|c|c|c|}
\hline Artifact & Type & Texture & Cortex \\
\hline Uniface & chert & fine (with inclusions) & present \\
\hline Uniface & chert & coarse & present \\
\hline Core & chert & fine (with inclusions) & present \\
\hline Core & chert & fine (with inclusions) & present \\
\hline Core & chert & fine (no inclusions) & present \\
\hline Core & chert & fine (no inclusions) & present \\
\hline Biface & chert & fine (with inclusions) & present \\
\hline Biface & chert & fine (no inclusions) & present \\
\hline Biface & chert & fine (with inclusions) & present \\
\hline Projectile Point & chert & fine (no inclusions) & absent \\
\hline Biface & chert & fine (with inclusions) & absent \\
\hline Biface & chert & fine (no inclusions) & absent \\
\hline Biface & chert & fine (with inclusions) & absent \\
\hline Biface & chert & fine (no inclusions) & present \\
\hline Biface & chert & fine (no inclusions) & present \\
\hline Biface & chert & fine (with inclusions) & present \\
\hline Biface & chert & fine (no inclusions) & present \\
\hline Biface & chert & fine (no inclusions) & present \\
\hline Biface & chert & fine (with inclusions) & present \\
\hline Biface & chert & fine (with inclusions) & absent \\
\hline Biface & chert & fine (with inclusions) & present \\
\hline Biface & chert & fine (no inclusions) & present \\
\hline Biface & chert & fine (with inclusions) & present \\
\hline Debitage & chert & fine (with inclusions) & present \\
\hline Debitage & chert & fine (no inclusions) & present \\
\hline Debitage & chert & fine (with inclusions) & present \\
\hline Debitage & chert & fine (with inclusions) & present \\
\hline Debitage & chert & fine (no inclusions) & present \\
\hline Debitage & chert & fine (no inclusions) & present \\
\hline Debitage & chert & fine (with inclusions) & present \\
\hline Debitage & chert & fine (no inclusions) & present \\
\hline Debitage & chert & fine (no inclusions) & present \\
\hline Debitage & chert & fine (no inclusions) & present \\
\hline Debitage & chert & fine (no inclusions) & present \\
\hline Debitage & chert & fine (with inclusions) & present \\
\hline Debitage & chert & fine (no inclusions) & absent \\
\hline Debitage & chert & fine (no inclusions) & present \\
\hline
\end{tabular}

\begin{tabular}{|l|r|r|r|r|}
\hline Artifact & absent & present & $\begin{array}{c}\text { Grand } \\
\text { Total }\end{array}$ & $\begin{array}{c}\% \text { Assemblage } \\
\text { minus Debitage }\end{array}$ \\
\hline Biface & 4 & 12 & 16 & $70 \%$ \\
\hline Core & $25 \%$ & $75 \%$ & & $17 \%$ \\
\hline & 0 & 4 & 4 & \\
\hline Debitage & $0 \%$ & $100 \%$ & & \\
\hline & 1 & 13 & 14 & \\
\hline Projectile Point & $7 \%$ & $93 \%$ & & \\
\hline Uniface & $100 \%$ & $0 \%$ & & \\
\hline & 0 & 2 & 2 & \\
\hline Grand Total & $0 \%$ & $100 \%$ & & \\
\hline
\end{tabular}



